\title{
Excavations of Portions of the San Pedro Acequia (41BX337) and a Search fro the Arocha Acequia, San Antonio, Texas
}

I. Waynne Cox

Follow this and additional works at: https://scholarworks.sfasu.edu/ita

Part of the American Material Culture Commons, Archaeological Anthropology Commons, Environmental Studies Commons, Other American Studies Commons, Other Arts and Humanities Commons, Other History of Art, Architecture, and Archaeology Commons, and the United States History Commons

Tell us how this article helped you.

This Article is brought to you for free and open access by the Center for Regional Heritage Research at SFA ScholarWorks. It has been accepted for inclusion in Index of Texas Archaeology: Open Access Gray Literature from the Lone Star State by an authorized editor of SFA ScholarWorks. For more information, please contact cdsscholarworks@sfasu.edu. 


\section{Excavations of Portions of the San Pedro Acequia (41BX337) and a Search fro the Arocha Acequia, San Antonio, Texas}

\section{Creative Commons License}

\section{(c) (1) \&}

This work is licensed under a Creative Commons Attribution-NonCommercial 4.0 International License 
EXCAVATIONS OF PORTIONS OF THE SAN PEDRO ACEQUIA (4I BX 337) AND A SEARCH FOR THE AROCHA ACEQUIA, SAN ANTONIO, TEXAS

I. Waynne Cox

Center for Archaeological Research The University of Texas at San Antonio Archaeological Survey Report, No. 161 
A 1 ist of publications offered by the Center for Archaeological Research can be obtained by sending $\$ 1.00$ to the Center for A.rchaeclogical Research, The University of Texas at San Antonic, San Antonic, Texas 78285. 


\section{ABSTRACT}

Upon notification that the upper San Pedro Acequia was known to be below the anticipated parking lot to be constructed for the VIA Metropolitan Transit System, the Texas Historical Commission (THC) contacted the Center for Archaeological Research. The University of Texas at San Antonio, to investigate and document the site. A representative from the THC examined the site and requested minimal excavation and documentation of the San Pedro Acequia in this location. We recommend that this portion of the San Pedro Acequia is eligible for nomination to the National Register of Historic Places.

Fol 1 owing the work on the San Pedro Acequia, the VIA Metropolitan Transit System contacted the CAR-UTSA to investigate another area prior to construction of a parking lot, where the Arocha Acequia was believed to be buried. The CAR-UTSA field crew found no indication that any trace of the Arocha Acequia survived in the area. We recommend no further work in this area. 


\section{TABLE OF CONTENTS}

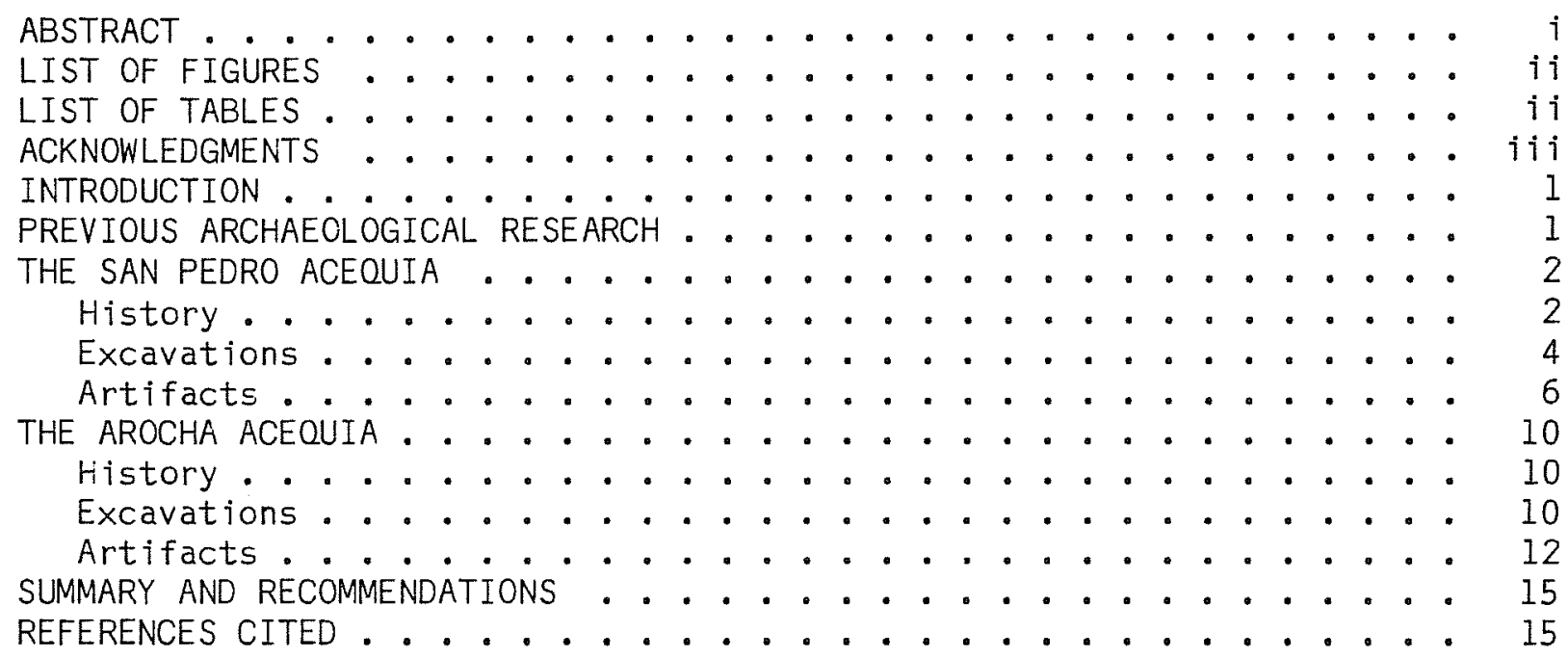

\section{LIST OF FIGURES}

1. Excavation Location for the San Pedro Acequia . . . . . . . . . . 5

2. Selected Artifacts from the San Pedro Acequia . . . . . . . . . . 9

3. Excavation Location in Search of the Arocha Acequia . . . . . . . . 11

4. Selected Artifacts from the Arocha Acequia Location . . . . . . . . 14

\section{LIST OF TABLES}

1. Provenience for Artifacts Recovered from the San Pedro Acequia . . . 7

2. Provenience for Artifacts Recovered During the Search for the

Arocha Acequia... . . . . . . . . . . . . . . 13 


\section{ACKNOWLEDGMENTS}

I would like to thank several individuals who have been particularly helpful in the completion of these investigations. The entire staff of the VIA Metropolitan Transit System, especially R. Neil Kravetz, is acknowledged for their cooperation, interest, and support. A special thank you is extended to John Lea 1 from the Bexar County Archives and Richard C. Garay, for their input and support in my research. 
Since neither time nor space allows for a complete discussion of the San Antonio acequia system, the reader desiring more complete history and descriptions is referred to other sources dealing with the subject in greater depth, such as Corner (1890), Arneson (1921), Holmes (1962), and Minor and Steinberg (1968).

Previous archaeological investigations of the San Antonio acequias were consulted, including excavations at the Acequia Madre, or Alamo Ditch (Scheutz 1970; Sorrow 1972; Adams and Hester 1973; Katz 1978; Cox 1985; Fox and Ivey n.d.). Previous investigations of the San Pedro Acequia were conducted on 1 ined sections of the acequia on the south side of the Bexar County Courthouse parking lot and on the grounds of the old Arsenal (Fox 1978a, 1978b). Investigations of the San Pedro Acequia between West Sheridan and West Guenther Streets revealed both 1 ined and un 1 ined sections of the acequia (Valdez and Eaton 1979; Frkuska 1981).

THE SAN PEDRO ACEQUIA

\section{History}

Although it is frequently stated that the oldest acequia in San Antonio is the Pajalache or Concepción Ditch (Corner 1890:43; Arneson 1921:123), or in some cases the Acequia Madre is given that distinction (Holmes 1962:7; Burkholder 1976:8; Buck 1980:105), a search of early 1iterature does not support these claims. In his diary of the Alarcon Expedition. Fray Francisco Celiz (1935:86) records,

On the 12th of said January [1719] although the weather was very severe and unusua 1, the Governor [A] arcon] gave orders to begin with al1 assiduity the construction of the canals for both the villa and the said mission of San Antonio de Balero [sic]. This work was continued the remainder of the said month, in which time they were built in good state and shape, so this year a fine crop of corn, beans, and other grains the Governor ordered brought in from the outside is expected.

Since, at that time, both the mission and the villa were situated west of the San Antonio River, near and below San Pedro Springs, this reference must be to the beginning of what would later be known as the San Pedro Acequia. The Acequia Madre, designed to service the mission after it moved to the east bank of the San Antonic River, was not begun unti1 1724 (Barker 1929:36-38).

Further proof of the early existence of the San Pedro Acequia is noted in a report to the governor in 1732, that the acequia is only adequate to sustain "15 vezinos" (citizens) and is inadequate to support both the "Vezinos Antiquos" (old citizens) and the newly arrived "las Familias Yslenas" (Is 1 and families, the Canary Islanders; Aviles 1732). It is 1 ikely that some improvements were effected at that time, for the acequia was to serve the citizens as the primary water supp $7 y$ for many more years.

During the Republic of Texas period (1836-1846), there were severa] ordinances enacted concerning the obligation of ". . a 11 those persons 


\section{INTRODUCTION}

On July 16, 1985, the Texas Historical Commission (THC) was informed that construction of a bus parking lot for the VIA Metropolitan Transit System might have impact upon an upper portion of the historic San Pedro Acequia in New City Block (NCB) 348, located to the northeast of the central downtown district of San Antonio. The Center for Archaeological Research (CAR), The University of Texas at San Antonic (UTSA) was contacted and was requested to investigate and document any cultura 1 resources associated with NCB 348. Thomas R. Hester, director, and Jack D. Eaton, associate director, of the CAR, served as principal investigators. The field crew consisted of I. Waynne Cox, research associate, and Roger Wayne Johnson, Ralph Snavely, Sy 1 via Reyna, and Cecil Pee1, technical staff assistants. The team began investigations on Ju1y 17, 1985, and completed their documentation on the following day. A backhoe, provided by the VIA Metropolitan Transit System, was used to excavate six trenches on the site; the acequia was exposed in three of these trenches. With the approval of the THC, on $7 y$ those artifacts encountered in the process of exposing the acequia were collected and curated.

In August 1985, the CAR was again contacted by the VIA Metropolitan Transit System of their intent to modify an automobile parking lot on NCB 1917, reported site of a portion of the Arocha Acequia. They requested that the CAR investigate for any remaining evidence of the acequia. The field crew consisted of I. Waynne Cox, Roger Wayne Johnson, technical staff assistant, and Bruce Merge le, CAR consultant. Supervision was provided by the same principal investigators. The crew conducted the field work on October 7-8, 1985. With a backhoe supplied by the VIA Metropolitan Transit System, a trench was excavated that measured 368 feet and 6 inches. No evidence was found of the acequia.

Both investigations were done under contract between the VIA Metropolitan Transit System and the Center for Archaeological Research, The University of Texas at San Antonio. The VIA Metropolitan Transit System's parking lot extension project was financed through a grant from the Urban Mass Transportation Administration. The archaeological field work was done in compliance with the National Historic Preservation Act of 1966 (as amended) and its implementing regulations, 36 CFR 800.

\section{PREVIOUS ARCHAEOLOGICAL RESEARCH}

Prehistoric and historic archaeological evidence in the immediate vicinity of the study area indicates that the various springs and watered areas around San Antonic have been intermittently occupied since Paleo-Indian times (Orchard and Campbel1 1954; Fox 1975). Although no specific sites have been identified in or about San Pedro Springs, it is felt they once existed but have been obliterated by modern construction (Orchard and Campbe 11 1954). The reports of the early Spanish entradas clearly indicate the springs were occupied by ". . . a populous rancheria of Indians.. . numbering in al1 about 500 persons.." (Espinosa 1709:5; see also Celiz 1935:87). 
whose property 1 ies on the acequia which crosses the city . . " to insure that it is cleaned and unobstructed (CCM March 13,1838, Vol. A:14; Feb. I, 1839, Vol. A:31; Jan. 10, 1840, Vol. A:36; Jan. 17, 1840, Vo1. A:37; Apri1 10, 1850, Vo1. II:102). In 1847, the City Council insured its supply of water by stipulating that every fifth day was specificaliy for the use of the city (CCM May 15: 1847, Vo1. C:250). In 1852, the City Council (CCM Jan. 13, 1852, Vol. II:58) entered into a contract,

- . for constructing a ditch across the Main Plaza in 1 ine of the present delapidated one of the following dimensions... 3 feet wide at the bottom and 4 feet at the top, solid masonery of stone 1 aid in sand and 1 ime, wal1 18 inches thick, to be paved at the bottom with flat stone.

The acequia was not 1 ined in its entirety, however, but primarily throughout the main portion of the city. This is indicated by the excavations between Sheridan and Arsenal Streets (Frkuska 1981) and the descriptions by Taylor (1902:71) of the acequia in 1902, where it is said to be ". . . two feet deep and six feet wide..."

By 1868, some of the downtown portion of the acequia had been provided with a covering, as is attested to by a near tragedy on Acequia (Main) Street, when a 2-1/2-year-old child fell into the ditch and was ". . . sucked out of sight by the current and before any covering could be torn away, floated a distance of several yards..." before being rescued (San Antonio Express 1868).

By 1877, the city finally established a modern water system (Sibley 1973:130), and the primary purpose for the acequia no longer existed. This was timely, for in the period from December 1897 to September 1900, San Antonio suffered a severe drought, and the springs ceased to flow (Taylor 1904). In 1891, the first artesian wel 1 was drilled, and the city turned to the Edwards Aquifer as its primary source of water (McLean 1924:11). With no further reason for its existence, the venerable waterway ceased to function by 1906 (Schuchard 1951:30) and was official1y closed in 1912 (CCM Sept. 3, 1912, VoT. V).

The 1 and through which the section of the San Pedro Acequia described in this report passes was first granted to Francisco Joseph de Arocha by the Spanish government in 1732, and was the sixth suerte drawn of the 1 ands awarded to the Canary Islanders (Spanish Archives V01. 2:5). Arocha was born in Palma, Canary Islands, in 1703. He joined the group in Quautitian, Mexico, and married Juana Curbelo, daughter of one of the initial families (Chabot 1937:167; Buck 1980:59). Since he was the only 1 iterate person among the Is 1 anders, Arocha was appointed escribano de consejo y pablico (public scribe and counse 1), the only man to so serve during the 18 th century (Chabot 1937:167). Upon his death, the property passed to one of his 15 heirs, Manua 1. However, in 1776, Manual ". . as a partitioner in an irrigation conduit which is under construction [the Upper Labor]. . I am without funds with which to continue paying my share..." and he deeded the property to his brother, Simon de Arocha (BCA-LGS 1776 no. 12). Simon was commandant of the Provincial Militia of the Villa de San Fernando de Bexar as wel 1 as a prominent cattle rancher with vast holdings in Wilson County 
(Chabot 1937:167-168). In 1826, a nephew, Jose Nepomescuno Arocha, sold the 1 and to George Antonio Nixon (BCDR Vol. VI:174; BCA-LGS 1776 no. 475).

Nixon was 1 and commissioner for the Galveston Bay and Texas Land Company which sold 1 and on the Empresario grants of David Gouverneur Burnet, Joseph Vehlein, and Lorenzo de Zavala (Branda 1976:654). Prior to that, and throughout his 1 ifetime, he acquired extensive 1 and holdings in Iowa, Missouri, Kentucky, Tennessee, New Mexico, Mexico, and Texas (BCDR Vol. W2:238). He died in Jasper County, Texas, prior to 1849 (Branda 1976:654). His estate passed to his on 1 y child, Priscil1a Ann Nixon Henrie Duffield, widow of John M. Henrie and wife of William C. Duffield. Upon Duffield's death in 1869, the estate passed to his daughters, Virginia Anne Gillum, by his first wife Anna Taylor Light, and her half-sister, Rosa (Rosanna) Yonque, by his second wife Priscilla Ann (BCDR Vol. W2:238, Vol. 19:68, Vo1. 23:144). They had the area platted and subdivided in November 1877 (BCDR Vol. 6:565). The lots under investigation, $01 d$ City B1ock 49 (now New City Block 348), Lots 1, 2, 3, and 4, were sold, with others, by Virginia and Henry Gillum to Maria de 1 os Santos Rodriquez, Martine Maria Antonio Rodriquez de Chavez, Juan F. Rodriquez, and Jose Maria Rodriquez in 1883 (BCDR Vo1. 21:581). The following year, they divided the property among themselves, with Jose Maria Rodriquez acquiring Lot 1, Maria Rodriquez de Chavez, Lot 2, and Maria de 1 os Santos Rodriquez, Lots 3 and 4 (BCDR Vo1. 33:249, 250, 254).

A search of the city directories of San Antonio indicates that no structures were constructed on the properties unti 11947 when Tom Spencer moved his 1 umber company from West Laurel Street to its new location at 702 Evergreen Street (City Directories 1885-1975). The VIA Metropol itan Transit System acquired the property from his widow in 1977 (BCDR Vo1. 8249:479).

\section{Excavations}

Using the backhoe supplied by the VIA Metropolitan Transit System, the initial trench was opened on Lot 6 on the extreme south edge of NCB 348 (T-1, Fig. 1). The location for this trench was selected because it was an open area and had not been affected by the lowering of the grade as had much of the rest of the block. Since the abandonment of the acequia ca. 1907, the area has experienced several leveling and fill episodes. All evidence indicated that the acequia had exited the block by this point, and the excavation was expected to give an undisturbed profile for future comparison. The trench, approximately 20 feet 1 ong and 5 feet deep, indicated no evidence of the acequia.

A second trench (T-2, Fig. 1) was opened on the south edge of Lot 4, north of the intervening construction trailer. The grade leveling, performed by VIA Metropolitan Transit System prior to the arrival of the archaeological team, had exposed traces of 1 imestone in this area that indicated evidence of some structure just below the surface, which had not yet impacted upon the acequia. Excavation by the archaeologist exposed a cut 1 imestone stone wal 1 in place on the west side, with a similar wall on the east, except it was col1 apsed inward. The wall is 18 inches thick, with a dressed face toward the interior of the acequia, set in a sandy yellow mortar. The width of the acequia at this location is approximately 5 feet; the exact width was 


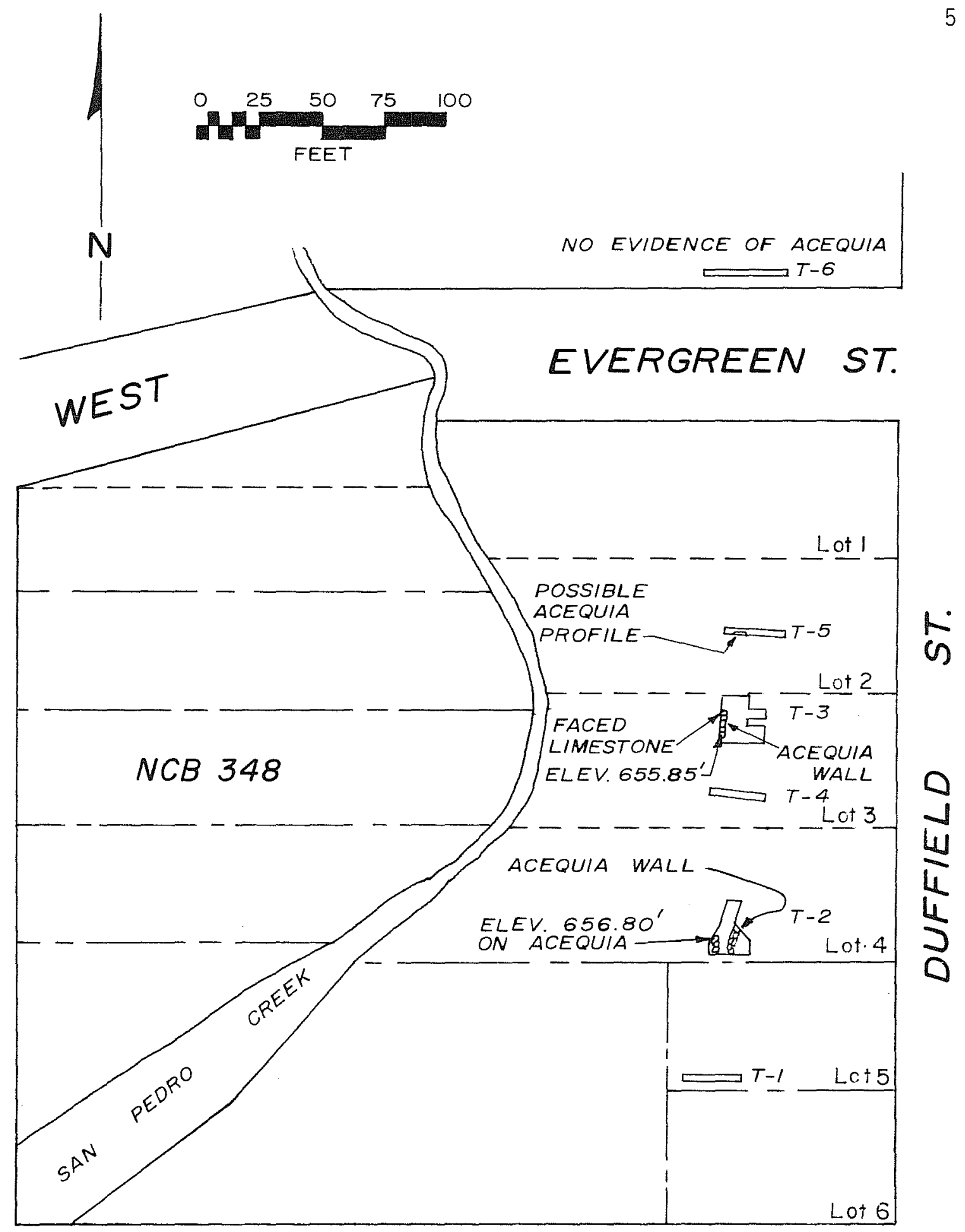

Figure 1. Excavation Location for the San Pedro Acequia. 
undetermined due to the collapsed condition of the east wal1. The path of the acequia at this point begins to curve toward the west.

Trench 3 was located to the north on Lot 2 (T-3, Fig. 1), and upon 1ocating the acequia, we followed it 15 feet to the north. The stone 1 ining stops at 10 feet, and the end stone is faced toward the interior on the northern edge. A cedar post is set vertically at the northern end. Again, the east wall had collapsed, but the corresponding end stone is also faced on the interior and northern end. The interior of the lined portion is filled with a brown, sandy loam. while the soil to the north of the 1 ined portion and the post contains a greenish gray, silty soil.

Trench 4 was placed midway between Trenches 2 and 3 (T-4, Fig. I); the area was found to be badly disturbed and filled with oil-sand, a surfacing material, and red brick to a depth of over 3 feet. The following day Trench 5 (T-5, Fig. 1) was opened on Lot 1. Again, there was no evidence of 1 ining, only a shallow ditch was exposed in the profile. No artifacts were found in association with either the ditch or the surrounding soil. A final trench was opened to a length of 34 feet on the north side of West Evergreen Street (T-6, Fig. 1). No evidence of either a 1 ined or unlined ditch was revealed. There was, however, evidence of recent disturbance to a considerable depth. All units were backfilled prior to leaving the site.

\section{Artifacts}

The artifacts recovered during the backhoe operation were removed to the 1 aboratory for analysis. The articles were cleaned, identified, classified, and catalogued. The artifacts have been divided into six categories according to their probable usage (Table 1). These categories are ceramics, glass containers, miscellaneous items, personal items, barn or workshop items, and construction materials. No artifacts were encountered in Trench I or 5, and none were collected from Trench 6 due to the recent nature of the disturbance.

A11 artifacts recovered date from the 20 th century (Fig. 2). This is probably due to two factors: first, the late closing date of the acequia (1906-1912) and, second, the nature of the excavations. The excavations were designed on $1 y$ to disclose the location of the acequia, and no excavations extended into the depth of the interior, therefore no earlier materials that may have been near the bottom were recovered. None of the artifacts differ substantially from those described and $i 11$ ustrated numerous times in previous reports on archaeology elsewhere in San Antonio (Frkuska 1981; Fox 1978a; Ivey 1978). 
TABLE 1. PROVENIENCE FOR ARTIFACTS RECOVERED FROM THE SAN PEDRO ACEQUIA

| Surface | Trench 2 | Trench 3 | Trench 4 | Tota1

CERAMICS

Decorated whiteware

Undecorated whiteware

Porcelain

Over glaze

Plain (Green)

Stoneware

GLASS CONTAINER FRAGMENTS

Clear

B1ue

Green

Brown

Aqua

White

Lavender

MISCELLANEOUS ITEMS

Caps

Iron scrap

Spoons

Forks

Openers

PERSONAL ITEMS

Buttons

Beads

Marbles

Watchcase back

Souvenir piece

Lens

Bicycle pedal

BARN/WORKSHOP ITEMS

Wire

Tools

Ornamental handle

Rubber tire

Raitroad spike

CONSTRUCTION MATERIALS

Window glass

Nails, wire

Sewer pipe

Electric insulator

TOTAL

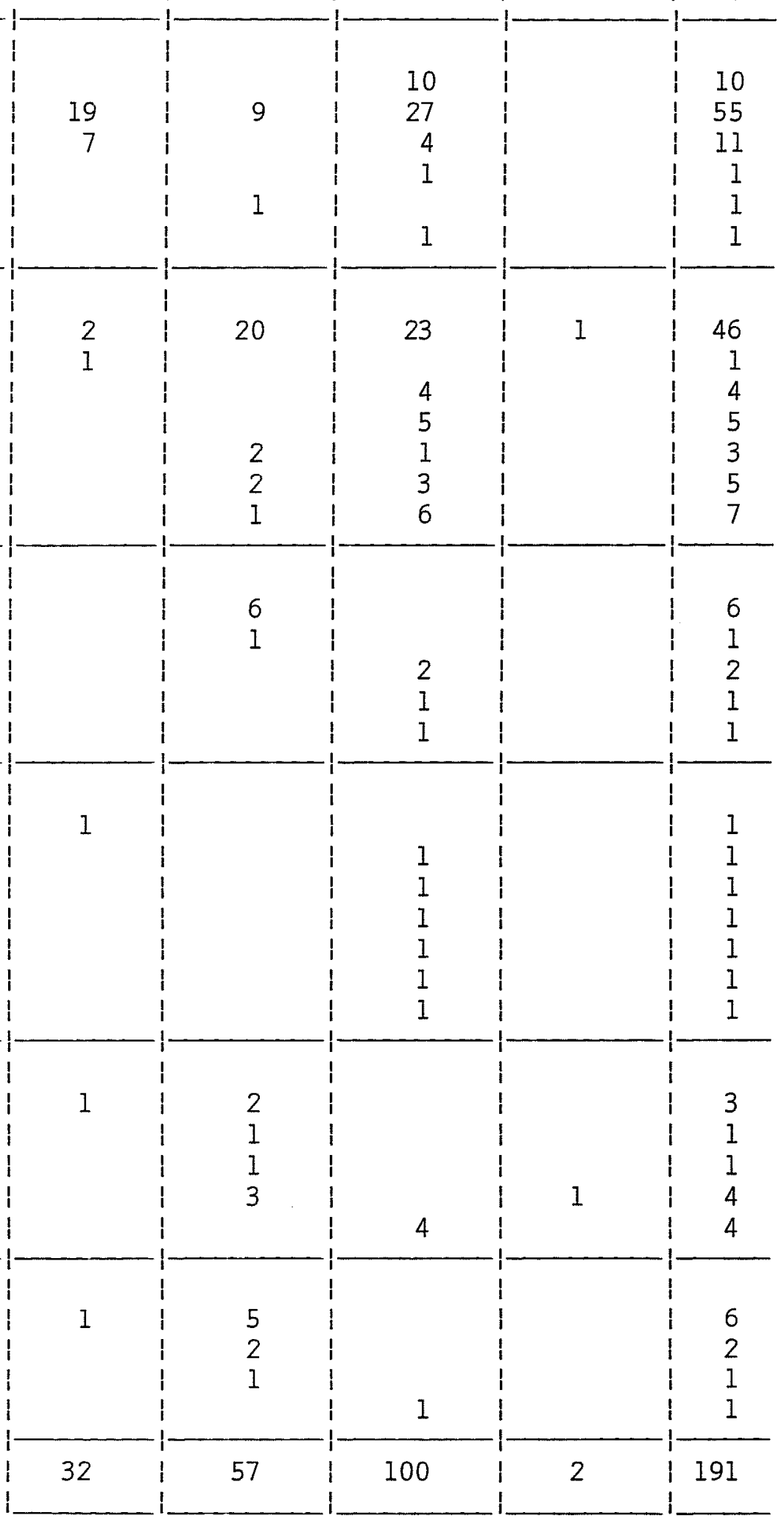


Figure 2. Selected Artifacts from the San Pedro Acequia.

a, stencil decorated whiteware, made in Germany;

b, souvenir token;

c, glass marble;

d, straight-sided Coca-Cola bottle (1900-1915);

e, two-piece mold made bottle, clear;

$f$, Vaseline jar (Chesebrough. New York);

g, cologne bottle (Hoyt's German cologne, W. Hoyt's Co., Lowe11, Mass.);

h, stoneware crock 1 id;

$i$, whiteware creamer. 

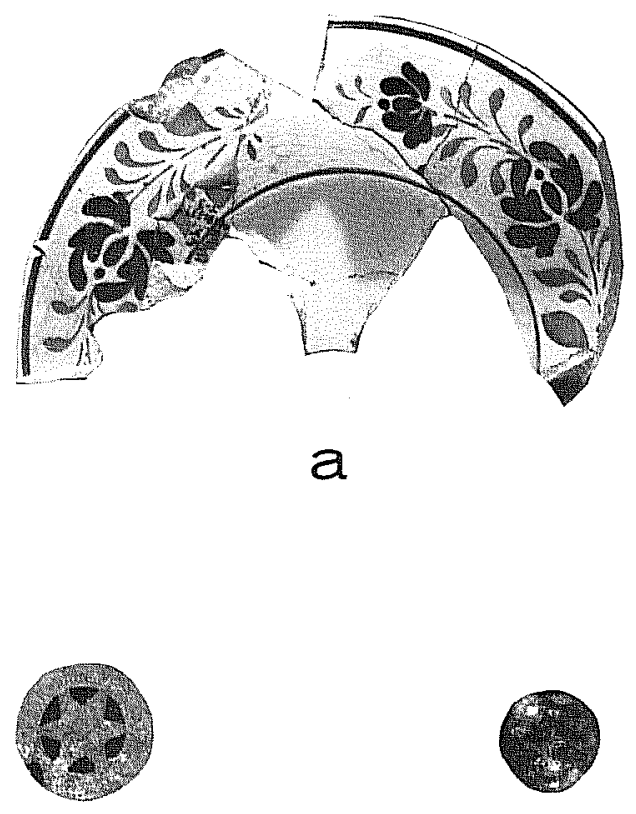

b

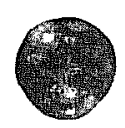

C

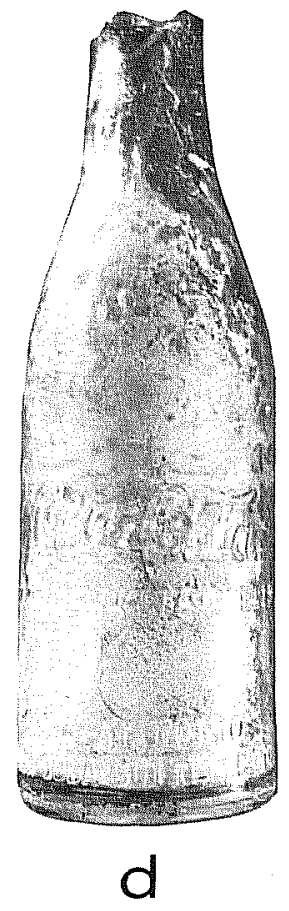

T.10.20.30.90.50.50
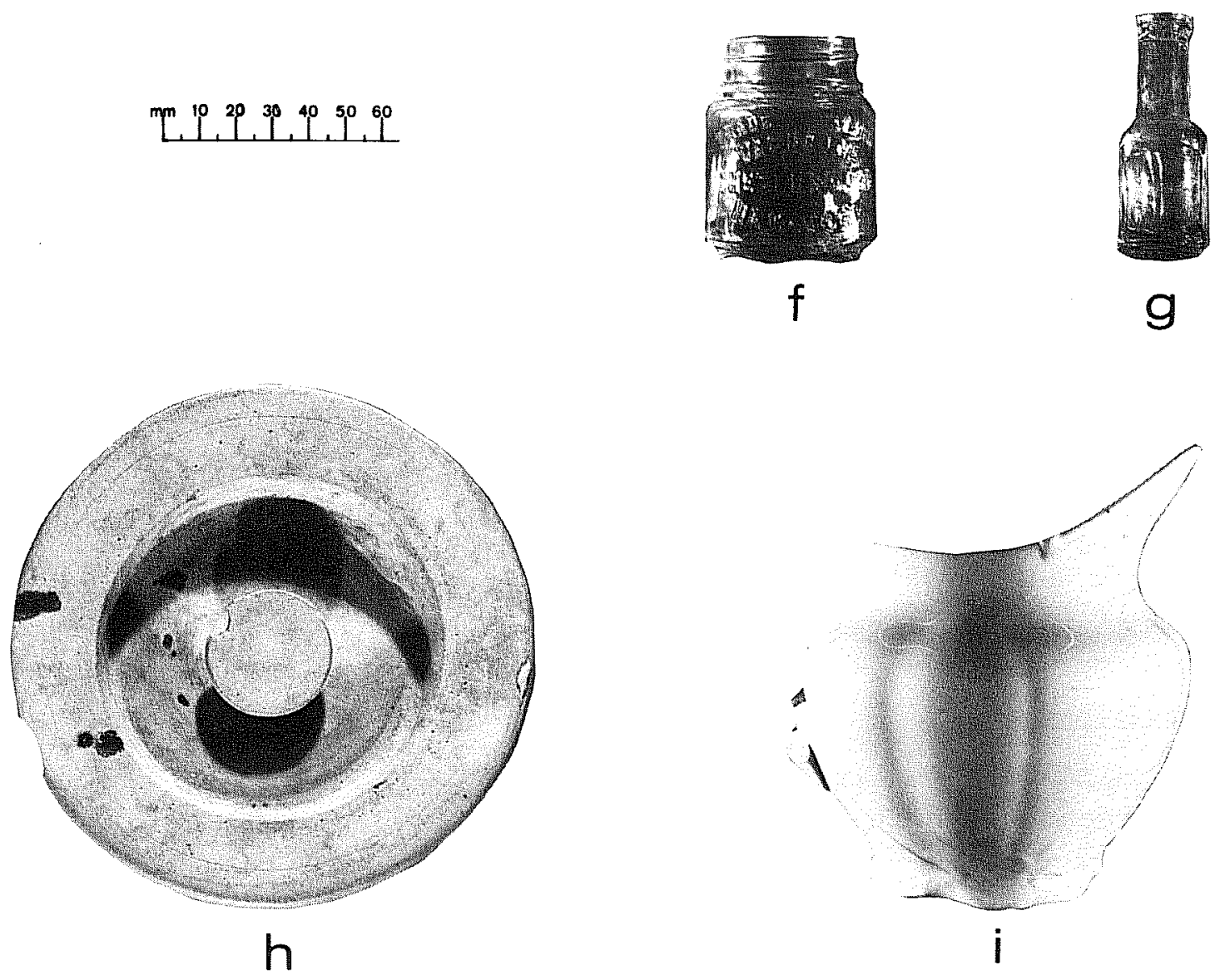
THE AROCHA ACEQUIA

\section{History}

The history of the Arocha Acequia is by no means as wel 1 documented as the other acequias of the San Antonio River valley. The only evidence of its existence is in a survey and map in the city surveyor's p 1 at book in 1850 (City Survey Book 1850 Vo1. 1:138). On that map the southern half of the acequia appears to have been closed by that time. It was a short acequia, never exceeding 410 varas ( 1138.5 feet) in length, and is the only known example of a private acequia. It was probably constructed for Francisco Arocha sometime after 1743, for in that year, he petitioned the City Council for ". . another piece of 7 and... On the other side of the creek, but has no water.." (BCA-LGS 1743 no. 2).

In 1851, the city of San Antonio, in an effort to define the two leagues of 7 and granted to it by the King of Spain, and reconfirmed by the Mexican Congress of Coahuila y Tejas, selected the 1 and in and about San Pedro Springs and initiated suit against those considered trespassers. The District Court returned a verdict in favor of the city, which was 1 ater affirmed by the Supreme Court in the case of Lewis et al. versus San Antonio (Crook 1967:27). The city then sold much of this 1 and to private individuals.

In 1852, the lots in question, along with others, were purchased by Sam S. Smith (BCDR Vol. L1:93). Smith, El Barbon ("big beard"), was mayor of San Antonio in 1847 and 1 ater served many years as county and district clerk (Chabot 1937:275; Buck 1980:285). He conveyed the 1 and to Wi1 1 iam Lange for $\$ 800$ in January 1865 (BCDR Vol. Tl:326). The 1 and in question, Lots 2 and 3 in Range 4, District 3 (now NBC 1917), was sold by Lange, in 1872, to Martin Muench for $\$ 5500$ (BCDR Vol. W2:295). Muench, a cotton and wool broker, subdivided the area into town lots and sold the tract to Peter Jonas, a saloon keeper and later county judge, who further subdivided the lots in 1884 (BCDR Vol. 8:523). He sold Lot 1 to Joseph Lack, Lot 2 to Miathida Toepperwein, and Lot 3 to Anton Fournier (BCDR Vol. 42:221, Vol. 34:313, Vol. 40:65). Joseph Lack conveyed Lot 1 to Valentine and Kate Obert, who constructed their home on the lot (BCDR Vol.48:92). William and Mathida Toepperwein resided on Lot 2 until after 1903, and it was occupied by their son. Thomas, until after 1927. The Fournier family occupied Lot 3 until after 1903 (City Directories 1896-1927).

\section{Excavations}

The crew arrived at the site, an unpaved parking lot on the corner of West Evergreen and North Flores Streets, on the morning of October 7, 1985. Trenching operations began at the sidewalk 1 ine parallel to West Evergreen Street and 23 feet to the south. The trench was extended to a length of 48 feet and 6 inches, with a depth of 4 feet (T-1, Fig. 3). The excavations revealed a profile of sterile soil, with only a shallow layer of disturbed soil near the surface. The second trench was again started at the sidewa $7 \mathrm{k}$ running toward the east, 44 feet south of the first trench (T-2, Fig. 3 ). Immediately revealed was red brick, concrete, and cut limestone, the 
$\mathbf{N}$

\section{N. FLORES ST.}

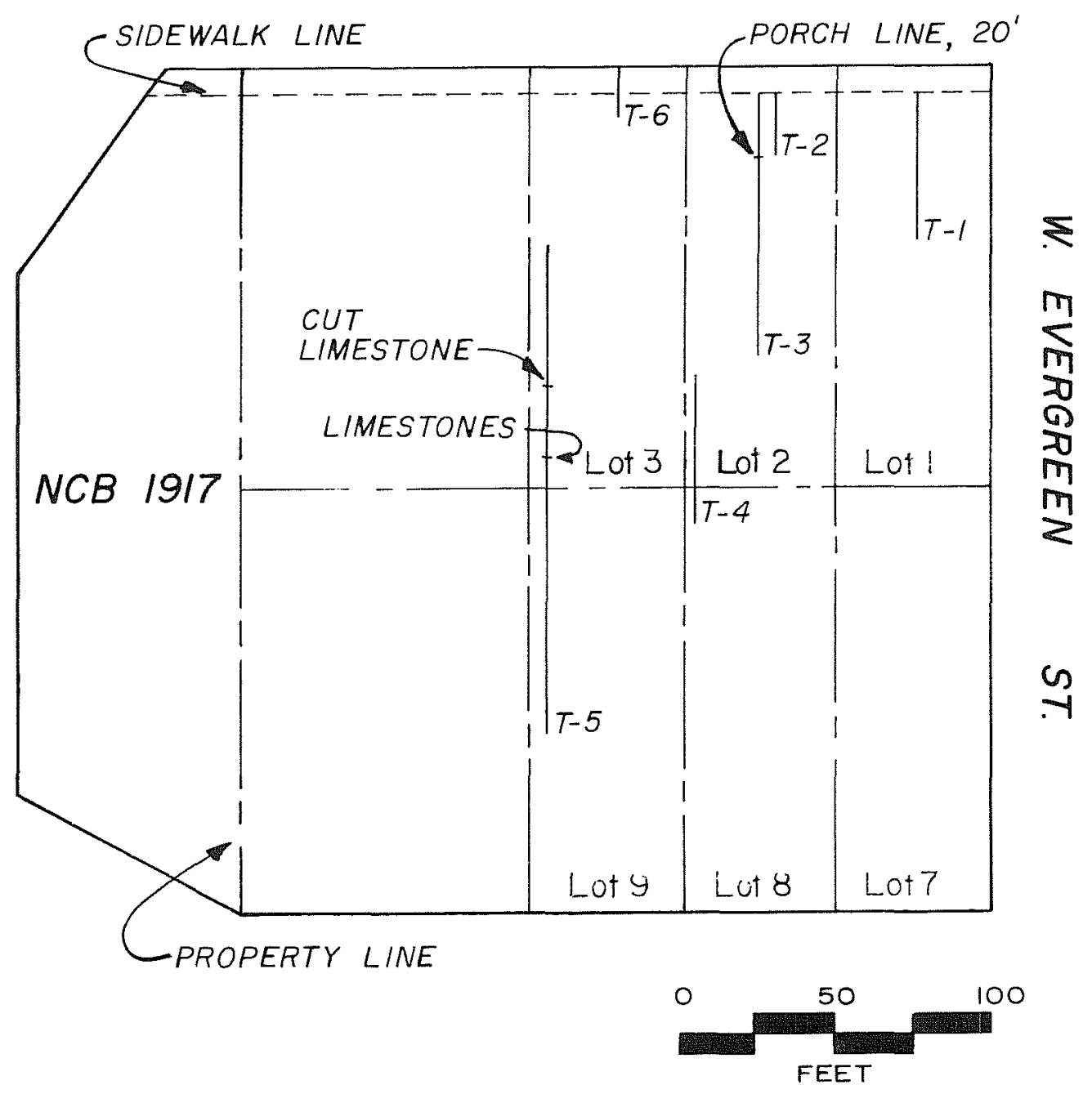

Figure 3. Excavation Location in Search of the Arocha Acequia. 
foundation of the house that had previously occupied the lot at 1618 North Flores Street, the Toepperwein residence. We discovered that we were excavating in the 1 ine of a 2-inch water main, and the trench was terminated at 18 feet. We then moved south 6 feet 8 inches and opened Trench 3 (T-3, Fig. 3). Twenty feet in from the curb 1 ine we encountered a cedar post, in place, that had served as a pier support for the porch, with associated household trash. This trench was extended to a length of 83 feet with no evidence of the acequia.

In order to insure that the acequia was not farther from the street 1 ine, the next trench (Trench 4 [T-4], Fig. 3) was begun 95 feet south of West Evergreen Street and 98 feet from the curb 1 ine of North Flores Street. The trench was extended to 48 feet in length, but proved to be disturbed throughout its length by the north wall line of the residence that had been the Fournier home.

The following day, Trench 5 (T-5, Fig. 3) was excavated on the southern edge of the property. At a distance of 97 feet from the curb 7 ine of North Flores Street, we exposed cut 1 imestone paving, eight inches below the present surface. Twenty-two feet farther east, we exposed a mortared stone wall, $1 \mathrm{~m}$ below the surface. The direction of the trench was reversed and extended toward the west. Fifty-five feet from North Flores Street, we encountered a huge mass of recent destruction rubble and trash, including a newspaper dated December 31, 1980. The direction of the trench was again reversed, eventually reaching a total length of 157 feet. Near the center of the block, the profile revealed that the eastern half of the 1 ot had received extensive fill, increasing toward the east.

The city plat map (City Survey Book 1850) indicated that the acequia should have been encountered approximately 30 feet east of North Flores Street, but in order to insure that it was not along the street 1 ine, the sidewa $1 \mathrm{k}$ was removed and a trench (Trench $6[T-6]$, Fig. 3) opened from the curb 1 ine. This trench was extended to a length of 14 feet in undisturbed soil with no evidence of the acequia. After having excavated 368 feet 6 inches of trench with no evidence of the acequia, the search was abandoned.

\section{Artifacts}

The artifacts encountered in the search for the Arocha Acequia were treated in the same manner as those acquired during the San Pedro Acequia excavations (Table 2). No artifacts were recovered from Trenches 2, 4, or 6.

The artifacts from the remaining three trenches could be confidently dated to the last half of the 19th century and well into the present century, as indicated by a 1980 newspaper. The artifacts from the 19th century, spongeware, Johnson Bros. Engl ish whiteware (1883-1913), Baker \& Co. Royal Stone China (1860-1893; Godden 1964:51, 355), and ear 1y transferwares, are consistent with the probable construction dates of the residences ( 1884 ; Fig. 4). The absence of 18th-century artifacts is probably due to the fact that, until the construction of the houses, the 1 and use was primarily agricultural. Again, none of the artifacts differ greatly from those previously reported elsewhere in San Antonic. 
TABLE 2. PROVENIENCE FOR ARTIFACTS RECOVERED DURING THE SEARCH FOR THE AROCHA ACEOUIA

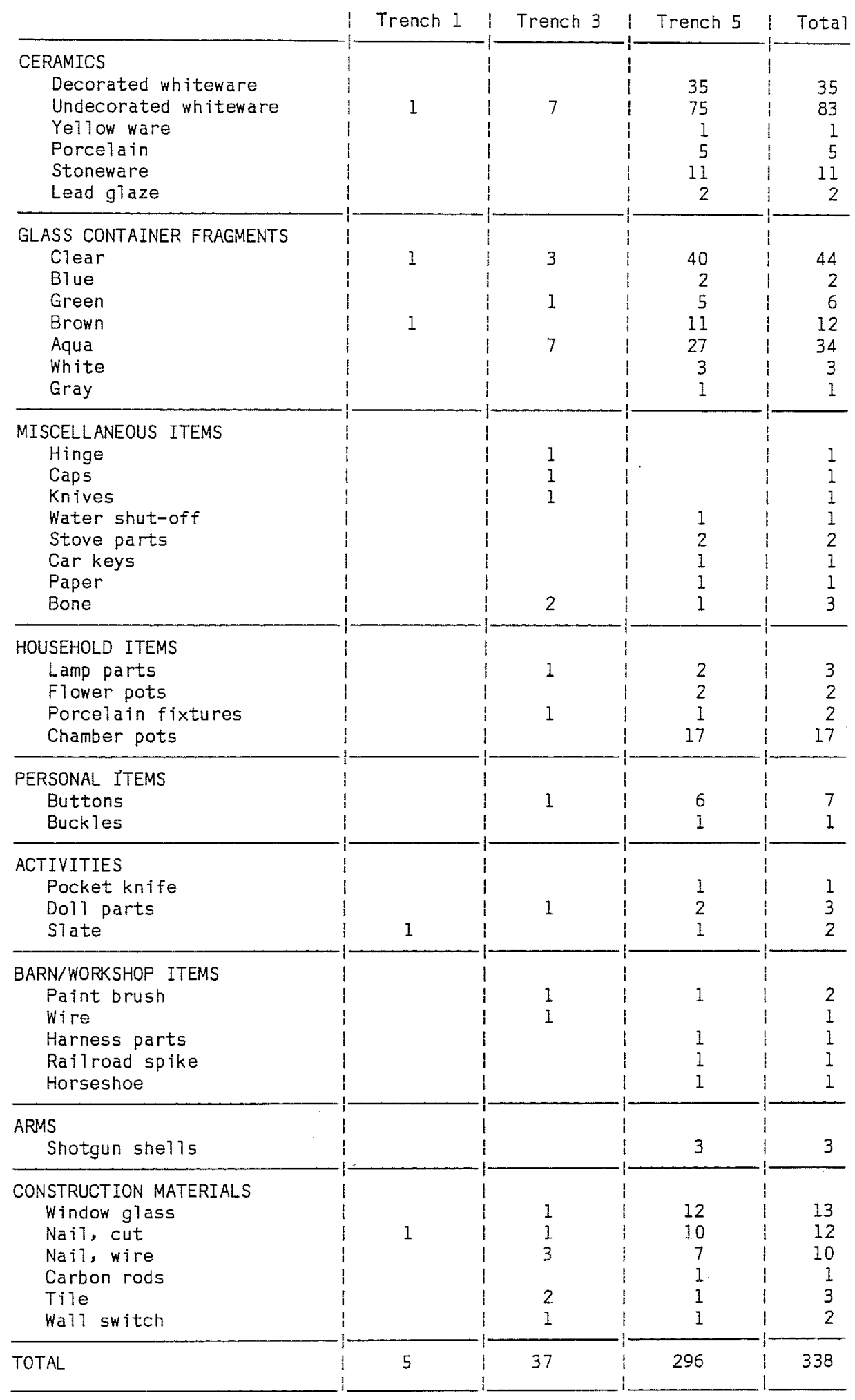



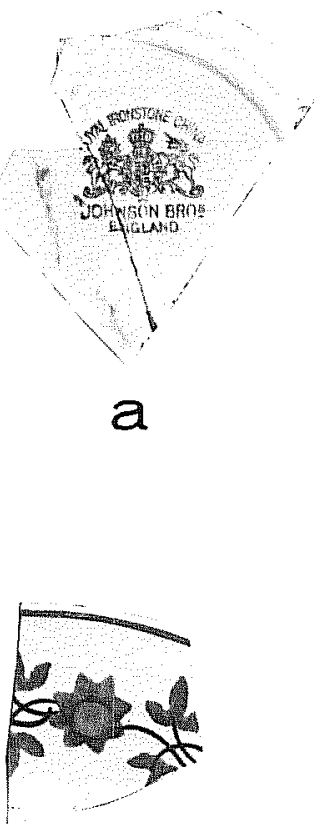

d

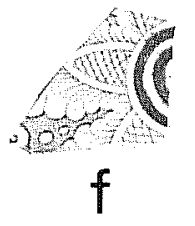

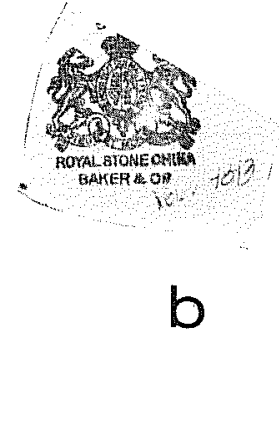
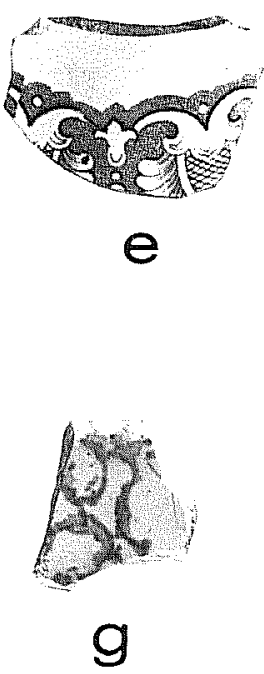

e

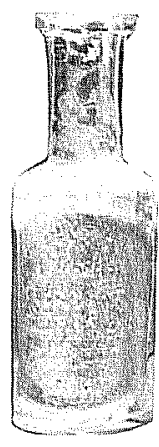

C
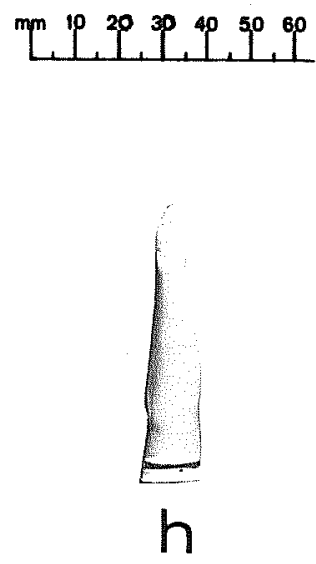

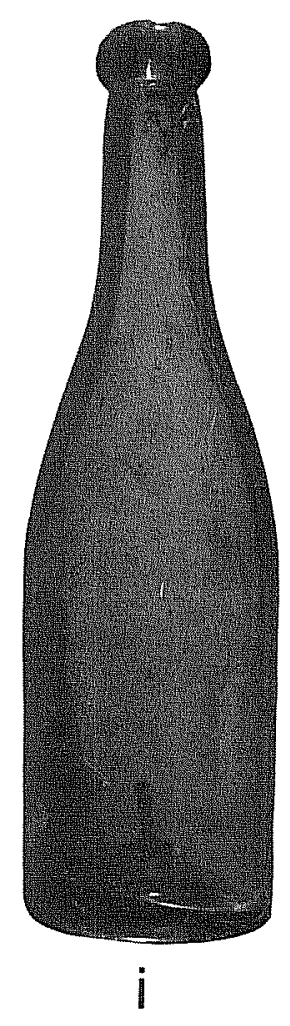

Figure 4. Selected Artifacts from the Arocha Acequia Location. a, whiteware, Roya 1 Ironstone China, Johnson Bros., England (1883-1913); b, whiteware, Royal Stone China, Baker \& Co. (1866-1893); c, two-piece molded bottle, with recess for 1 abel; d, cut sponge decorated whiteware; e, brown decal decorated whiteware; $f$, red decal decorated whiteware; g, sponge decorated earthenware (b1ue on white); h, china doll's arm for "stuffed body" type; $i$, olive glass ale bottle, blown-in turn mold with applied 1 ip. 


\section{SUMMARY AND RECOMMENDATIONS}

As a result of our investigations of the San Pedro Acequia, we now know the northern starting point of the stone 1 ining, approximately 470 yards south of San Pedro Springs. As the acequia left NCB 348, it began a gentle curve that would carry it over to paral1el North Flores Street. In the next block south, NCB 349, there once existed a canoa or wooden trough that carried its waters over the crossing of the Upper Labor Acequia. Our excavations of the un 1 ined portion of the San Pedro Acequia confirmed Taylor's (1902:71) figures as to its shallowness. At the time of our excavations, the proposed VIA Metropolitan Transit System's bus parking lot had already been bladed to the required grade level, and no further intrusion into the acequia was anticipated. Therefore, no further work is recommended at this time, since the planned 6-inch concrete cap wi 11 be more than adequate to protect any cultural resources. However, if in the future any excavation below this level is anticipated, suitable archaeological investigations should be provided. We recommend that this portion of the San Pedro Acequia is eligible for nomination to the National Register of Historic Places.

Our excavations in NCB 1917 indicate that there does not appear to be any remaining evidence of the Arocha Acequia in this block. In al 1 probability this acequia was a 1 ways a shal 10 w channe1, and the 1 itt 1 e evidence of its existence seems to indicate that it was abandoned as early as 1850. The episode of fill observed in Trench 6 near the center of the block would 1ead one to believe that it was obliterated when the block was leveled, probably when construction began in 1884. Since the intended parking lot is to be paved, no further work is recommended in this area. The investigations revealed no remaining evidence of the Arocha Acequia, therefore it is not considered eligible for nomination to the National Register of Historic Places.

\section{REFERENCES CITED}

Adams, R. E. W. and T. R. Hester

1973 Letter to Dr. Fred Wendorf, Texas Antiquities Committee, concerning completion of excavations at Mission San Antonio de Valero. November 26. On file at the Center for Archaeological Research. The University of Texas at San Antonio.

Arneson, E. P.

1921 Early Irrigation in Texas. Southwestern Historical Quarterly $25: 121-130$.

Aviles, Antonio de

1732 Carpetá de correspondencia de 7 as Provincias Internas por $70 s$ años de 1726 a 1731. Con los Excelentisimos, Señores Marques de Casa y Fuente Conde de Fuen Clara, También comprende alguna correspondencia hasta el año de 1736, Gobierno del Ylustrisimo Señor Vizazzon. Archivo General Nacional, Mexico, Richard C. Garay Collection, Volume 236:28, San Antonio, Texas. 
Barker, E. C., editor

1929 Texas History. Southwest Press, Dallas, Texas.

Bexar County, Texas

Bexar County Archives (BCA)

Land Grants and Sales (LGS)

1743 Donation of 7 and to Francisco Joseph de Arocha. April 24. Translation in office of Bexar County Archives, Bexar County Courthouse, San Antonio, Texas.

1776 Sale of 1 and by Manuel de Arocha to Simon de Arocha. August 10. Translation in office of Bexar County Archives, Bexar County Courthouse, San Antonio, Texas.

\section{Bexar County Deed Records (BCDR)}

1808- Originals and microfilm in the Bexar County Courthouse, 1979 San Antonio, Texas.

Branda, E. S., editor

1976 The Handbook of Texas, A Supplement. Volume III. The Texas State Historical Association, Austin, Texas.

Buck, S. M.

1980 Yanaguana's Successors, the Story of the Canary Is 1 anders' Immigration into Texas in the Eighteenth Century. Originally published in 1949. Naylor Publishing Company, San Antonio, Texas.

Burkholder, M. V.

1976 Down the Acequia Madre in the King William Historic District. Privately printed, San Antonio, Texas.

Celiz, Fray Francisco

1935 Diary of the Alarcon Expedition into Texas, 1718-1719. Fritz Len Hoffman, trans 7 ator. The Quivira Society, Los Angeles, California.

Chabot, F. C.

1937 With the Makers of San Antonio. Artes Graficas, San Antonic, Texas. 


\section{City Directories \\ 1896- Located at the Daughters of the Republic of Texas Research 1957 Library at the Alamo, San Antonio, Texas.}

City of San Antonic

City Council Minutes (CCM)

1836- City Secretaries Office. City Hal1, San Antonio, Texas. 1852

1850 City Survey Book. Volume 1. City Engineers Office, City Ha11, San Antonio, Texas.

Corner, W.

1890 San Antonio de Bexar: A Guide and History. Bainbridge and Corner, San Antonio, Texas.

Cox, I. W.

1985 loth Street Substation Excavation of the Acequia Madre (41 BX 8), San Antonio, Bexar County, Texas. Center for Archaeological Research, The University of Texas at San Antonio, Archaeological Survey Report 153.

Crook, C. E.

1967 San Pedro Springs Park. Privately printed, San Antonio, Texas.

Espinosa, Fray Isidro

1709 The Espinosa-01ivares-Aguire Expedition of 1709: Espinosa's Diary. Rev. Gabriel Tous, translator. Preliminary Studies of the Texas Cathol ic Historical Society l(III).

Fox, A. A.

1975 An Archaeological Assessment of the Southern Portions of the 01 mos Basin, Bexar County, Texas. Center for Archaeological Research. The University of Texas at San Antonio, Archaeological Survey Report 9.

1978a Preliminary Archaeological Assessment of South Parking Lot Area (Phase I) Site of Courthouse Annex, San Antonio, Texas. Letter report to Bexar County Commissioner Court. On file at the Center for Archaeological Research. The University of Texas at San Antonio.

1978b Archaeological Investigation of Portions of the San Pedro and A 1 azan Acequias in San Antonio, Texas. Center for Archaeological Research. The University of Texas at San Antonio, Archaeological Survey Report 49. 
Fox, A. A. and J. E. Ivey

n.d. Excavations on the west wall of the Alamo. Manuscript in preparation, Center for Archaeological Research, The University of Texas at San Antonio.

Frkuska, A. J., Jr.

1981 Archaeological Investigations of the San Pedro Acequia, San Antonio, Texas. Center for Archaeological Research, The University of Texas at San Antonio. Archaeological Survey Report 103.

G1 ick, T. F.

1972 The 01d World Background of the Irrigation Systems of San Antonio, Texas. University of Texas at El Paso, Texas Western Monograph 35. Texas Western Press, El Paso, Texas.

Godden, G. A.

1964 Encyclopaedia of British Pottery and Porcelain Marks. Bonanza Books, New York.

Holmes, W. H.

1962 The Acequias of San Antonio. Masters thesis, St. Mary's University, San Antonio, Texas.

Ivey, J. E.

1978 Archaeological Investigations at the Mayer House (41 BX 326), San Antonio, Texas. Center for Archaeological Research, The University of Texas at San Antonio. Archaeological Survey Report 59.

Katz, P. R.

1978 Archaeological and Historical Investigations in the Arciniega Street Area, Downtown San Antonio, Texas. Center for Archaeological Research, The University of Texas at San Antonio, Archaeological Survey Report 61.

McLean, B. J.

1924 The Romance of San Antonio's Water Supply and Water Distribution. San Antonio Printing Company, San Antonio, Texas.

Minor, J. E. and M. L. Steinburg

1968 A Brief on the Acequias of San Antonio. San Antonio Branch of the Texas Section. American Society of Civil Engineers. 
Orchard, C. D. and T. N. Campbell

1954 Evidences of Early Man from the Vicinity of San Antonic, Texas. The Texas Journal of Science $6(4): 454-465$.

San Antonio Express

1868 Narrow Escape. Wednesday, July 1, 1868. Microfilm in San Antonio Public Library. San Antonio, Texas.

Schuchard, E.

1951 100th Anniversary, Pioneer Flour Mills, San Antonio, Texas, 1851-1951. Naylor Publishing Company, San Antonio, Texas.

Schuetz, M. K.

1970 Excavation of a Section of the Acequia Madre in Bexar County, Texas, and Archeological Investigations at Mission San José in Apri], 1968. Texas Historical Survey Committee, Archeological Report 19.

Sibley, M. M.

1973 George W. Brackenridge, Maverick Philanthropist. University of Texas Press, Austin. Texas.

Sorrow, W. M.

1972 Archeological Salvage Excavations at the Alamo (Mission San Antonio de Valero) 1970. Texas Archeological Salvage Project, The University of Texas at Austin, Research Report 14.

Spanish Archives

3 volumes. Translations in the General Land Office, Austin, Texas.

Taylor, T. H.

1902 Irrigation Systems of Texas. Department of the Interior, Water Supp $1 y$ and Irrigation Paper 71, Series I, Irrigation 13. Government Printing Office, Washington, D.C.

1904 The Water Powers of Texas. Department of the Interior, Water Supply and Irrigation Paper 105, Series N, Water Power 7. Government Printing Office, Washington D.C.

Valdez, F., Jr. and J.D. Eaton

1979 Preliminary Archaeological Investigations of a Part of the San Pedro Acequia. San Antonio, Texas. Center for Archaeologica 1 Research. The University of Texas at San Antonio, Archaeologica 7 Survey Report 85. 
